\title{
Sportsmanship Orientations of University Students Receiving Education in Sports
}

\author{
Mehmet Yanik $^{1}$ \\ ${ }^{1}$ School of Physical Education and Sport, Balikesir University, Turkey \\ Correspondence: Mehmet Yanik, Balıkesir University, Physical Education and Sports School, Balıkesir, Turkey. \\ E-mail: mehmettyanik@gmail.com
}

Received: June 1, 2019

Accepted: June 21, 2019 Online Published: July 13, 2019

doi:10.5539/hes.v9n3p79

URL: https://doi.org/10.5539/hes.v9n3p79

\begin{abstract}
The aim of this study was to examine the sportsmanship orientations possessed by university students who were receiving training in the field of sports education with regard to certain variables. The study was designed in the survey model. The "Sportsmanship Orientation Scale" was applied to a total of 566 students, selected with the random sampling method, studying at Balıkesir University.

The research findings revealed that the mean sportsmanship orientation level of the participants was $3.45 \pm 0.63$. A significant difference in favour of female participants was observed for the scale as a whole and in the subdimensions. With regard to the variable of department attended, it was determined that students studying in the sport management department had higher levels of sportsmanship. According to the class level variable, it was determined that students in the third grade had the lowest levels of sportsmanship orientations. In the "respect for opponents" subdimension, it was determined that participants who played team sports had higher levels of sportsmanship orientations.

In conclusion, with the aim of increasing sportsmanship orientation levels of university students receiving training in the field of sports sciences, it is recommended that more attention should be given to the subjects of sports ethics and values education in course curricula.
\end{abstract}

Keywords: sport, fair play, sport ethics, sportsmanship

\section{Introduction}

When considered as a social activity with the interactions it forms, sport is a social phenomenon that reflects social value judgements (Weiss, 2001). The main affected areas of sport, which has a great effect in all areas of life, in a sociocultural context are immoral and unethical sporting behaviours. To prevent such unwanted behaviours in sport, first and foremost, it is necessary to increase the number of athletes who can succeed in behaving in a sportsmanlike way and the number of moral educators who train them.

The concept of sportsmanship has been described in different dimensions by many researchers. Stornes and Brue (2002) describe this concept as behavioural tendencies that determine how all individuals involved in sporting activity will behave in keeping with the spirit of sport. Another researcher, Cremades (2014), defines sportsmanship as moral attitudes and behaviours in sport. According to the common inference made from these definitions, sportsmanship is defined as moral and ethical types of behaviour (Stewart, 2014). Individuals engaging in sporting activity are expected above all to obey the rules of the game, show respect to their opponents and always display correct behaviour in the activities (Siedentop et al., 2004; Hacıcaferoğlu et al., 2015). If these rules and principles are not adhered to, however, it is not possible to speak of sportsmanship or sport ethics.

Sport ethics does not only mean simply obeying the rules of the game; it also means being able to show respect to opponents without succumbing to the will to win, and to display a fair and honest game without discrimination (Veronica \& Masari, 2011; Tel, 2014; Tanrıverdi, 2012). According to the Olympic ideal, the essence of sport is not to win the race, but to participate in the race (Toohey, \& Veal, 2000).

Training athletes who can display sportsmanlike behaviours is an important duty of societies. Educational institutions play an important role in the acquisition of these behaviours. Both the training of athletes and the creation of awareness of the concept of sportsmanship while educating trainers can be achieved with the 
curricula planned by schools and sports clubs (Ford, Jubenville \& Phillips, 2012). In the course of sports training, fundamental values such as the rivalry, equality of opportunity, cooperation, collaboration and tolerance that exist within the natural structure of lessons are considered as opportunities for individuals to acquire moral behaviours (Yllmaz et al., 2017).

It is a known fact that physical education has a number of positive effects on people's lives. One of these effects is the acquisition of positive behavioural skills. Positive behaviours expected from individuals who engage in sport are described in English by the expression "fair play". This concept is used in Turkish to describe sportsmanlike behaviours, and fair and honest play (Koç, 2013). The fact that sport, which used to be played only in an amateur spirit, has nowadays become something which is done as a professional occupation, and that athletes and clubs now have more of a desire to win, has to some extent damaged the spirit of sport. In sport that is played with the desire to win at whatever cost, an athlete may exhibit unethical behaviour in order to achieve his/her sporting aim (Vallerand \& Losier, 1994). For this reason, in the world of sport nowadays, the majority of behaviours that do not conform to the spirit of fair play give rise to the thought that a sufficient sport ethic and sports culture have not been created in individuals (Veronica \& Masari, 2011). For the development of a feeling of sportsmanship, it is considered important that students and athletes are guided and given the necessary education primarily by their teachers, school principals, trainers, club managers and families. It is thought that schools and sports clubs are the places where this education is most easily carried out.

Organising the training to be given in schools and sports clubs in a way that will teach and sustain the concept of fair play will contribute significantly to the propagation of such behaviours in society (Pehlivan, 2004). In addition, such training will gain different perspectives on events while gaining technical knowledge and skills (Öztürk \& Soytürk, 2015). [In this context, it is important that especially physical education teachers, coaches, and students of sports education who are prospective sports managers should be informed about this subject.

Examining the curricula of the relevant departments in universities, it is seen that the subject of fair play is included either as an elective course in undergraduate programmes or to a limited extent in lessons. Considering that students receiving education in sport are the sports instructors of the future, it is believed that more priority should be given to these subjects.

With this information in mind, the aim of this study is to examine the sportsmanship orientations of students receiving training at physical education and sports school with regard to certain variables.

\section{Method}

\subsection{Research Model}

The research is a descriptive study in the survey model that aims to determine the sportsmanship orientations of students in schools of physical education and sports and to compare these according to various variables.

\subsection{Study Group}

The study group of the research consists of 566 people studying in different departments of the physical education and sports school of Balıkesir University.

Demographic information about the participants is given in Table 1.

Table 1. The demographic data of the participants

\begin{tabular}{llll}
\hline Variables & Groups & $\mathbf{( N )}$ & $\mathbf{\%}$ \\
\hline Gender & Female & 230 & 40.6 \\
Type of Sport Played & Male & 336 & 59.4 \\
& Individual Sports & 187 & 33.0 \\
Department & Team sports & 379 & 67.0 \\
& PES Teaching & 143 & 25.3 \\
\multirow{3}{*}{ Grade } & Coach Training & 210 & 37.1 \\
& Sports Management & 213 & 37.6 \\
& First grade & 130 & 23.0 \\
Total & Second grade & 145 & 2.6 \\
& Third grade & 132 & 23.3 \\
& Fourth grade & 129 & 28.1 \\
& & $\mathbf{5 6 6}$ & $\mathbf{1 0 0}$ \\
\hline
\end{tabular}




\subsection{Data Collection Tools}

The "Sportsmanship Orientation Scale" (SOS), which was developed by Vallerand et al. (1994), and for which the Turkish adaptation and validity-reliability study were performed by Balçıkanlı (2010), was used as the data collection tool. 5 items of the original scale, which is composed of 25 items and 5 subscales, were observed not to suit the Turkish adaptation carried out by Balçıanlı (2010). The Turkish version of the scale, therefore, is a 20-item scale with a total of 4 dimensions, namely "Adherence to Social Conventions", "Respect for Rules and Officials", "Commitment to Responsibility in Sport" and "Respect for Opponents". The lowest score that can be obtained from these dimensions is 5 , while the highest is 25 . In this context, a score of 5-10 constitutes a low-level score (1-2), 11-19 is a medium-level score (3), and 20-25 is a high-level score (4-5).

Balçıkanl (2010) calculated the reliability coefficients of the subdimensions of the scale as 0.86 for the first factor, 0.83 for the second factor, 0.91 for the third factor and 0.82 for the fourth factor, and determined that the reliability values of the subdimensions of the scale were high.

In the reliability analysis of the current study, the reliability coefficient for the whole scale is 0.877 . Since coefficients greater than 0.65 are considered sufficient in studies related to reliability (Cronbach, 1990), the reliability level of the scale and the items it contains is regarded as sufficient.

In the evaluation of the scale, the arithmetic means and standard deviation values of the scores obtained by the participants from the scale and its subdimensions were examined.

\subsection{Data Analysis}

The data obtained within the scope of the research were analysed using SPSS software. When determining the suitable type of analysis for evaluating the data, the number of subjects $(\mathrm{n}=566)$, and whether or not the data showed normal distribution and had a homogeneous structure, were examined. It was seen that the data met the parametric test assumptions.

The data were analysed using the t-test and one-way analysis of variance (ANOVA) descriptive statistical methods. To determine from which groups the significant differences originated, Tukey's multiple comparison test was used. A significance level of $(\mathrm{p}<0.05)$ was used for all tests.

\section{Results}

The arithmetic mean of the total scores obtained by the participants of the study from the Sportsmanship Orientation Scale was $X=3.45 \pm 0.603$. Examining the SOS based on the subdimensions, the lowest mean score was 3.39 in the "Commitment to Responsibility in Sport" and "Respect for Rules and Officials" dimensions, followed by 3.41 in the "Respect for Opponents" dimension and 3.58 in the "Adherence to Social Conventions" dimension.

Table 2. Analysis of Sportsmanship Orientation Scores according to "Gender" Variable

\begin{tabular}{llllll}
\hline Scale/Sub Scale & Group/N & Mean & St.d & t & p \\
\hline Sportsmanship Orientation Scale & Female (230) & 3.583 & .613 & 4.410 & .000 \\
& Male (336) & 3.359 & .579 & & \\
Adherence to Social Conventions & Female (230) & 3.710 & .751 & 3.311 & .001 \\
& Male (336) & 3.506 & .696 & & \\
Respect for Rules and Officials & Female (230) & 3.581 & .788 & 4.848 & .000 \\
& Male (336) & 3.274 & .706 & & \\
Commitment to Responsibility in Sport & Female (230) & 3.527 & .652 & 3.774 & .000 \\
& Male (336) & 3.310 & .685 & & \\
Respect for Opponents & Female (230) & 3.513 & .678 & 3.101 & .002 \\
& Male (336) & 3.345 & .600 & & \\
\hline
\end{tabular}

The findings of the independent samples t-test performed to determine whether there were any significant differences between sportsmanship orientation levels of the participants of the study according to gender are presented in Table 2. The test results reveal a significant difference in favour of female participants for both the scale as a whole and for the subdimensions [t $(564)=4.41, \mathrm{p}<.05]$.

To determine whether the sportsmanship orientation levels of the participants of the study differed according to variable of the department they studied at, ANOVA test analysis was performed. The findings are reported in Table 3 . 
As can be seen in Table 3, a statistically significant difference at $p<0.05$ level was determined between the groups for the scale as a whole $[\mathrm{F}(2,563)=7.265 ; \mathrm{p}<0,05]$. This difference was seen to originate from the fact that participants attending the sport management department had higher levels of sportsmanship orientation than participants attending the other departments.

To determine whether the sportsmanship orientation levels of the participants of the study differed according to another variable, that of class level, ANOVA test analysis was performed. The findings are reported in Table 4.

According to the findings obtained in Table 4, a statistically significant difference at $p<0.05$ level was determined between the groups for the scale as a whole $[\mathrm{F}(3,562)=7.463 ; \mathrm{p}<0,05]$. This difference was seen to originate from the fact that participants studying in the third year had lower levels of sportsmanship orientation than participants studying in the other grades.

The sportsmanship orientation levels of the participants of the study were examined according to the type of sport they played, and the results of the t-test performed to establish whether there were any significant differences between the groups are displayed in Table 5 .

Table 3. Analysis of Sportsmanship Orientation Scores according to "Department" Variable

\begin{tabular}{lllllll}
\hline Scale/Sub Scale & Department & N & X & St.d & F & P \\
\hline Sportsmanship Orientation Scale & PES Teaching & 143 & 3.371 & .701 & & \\
& Coach Training & 210 & 3.379 & .737 & 7.265 & .001 \\
& Sports Management & 213 & 3.573 & .283 & & \\
& Total & 566 & 3.450 & .603 & & \\
Adherence to Social Conventions & PES Teaching & 143 & 3.542 & .847 & & \\
& Coach Training & 210 & 3.569 & .886 & & \\
& Sports Management & 213 & 3.640 & .379 & .900 & .407 \\
& Total & 566 & 3.589 & .725 & & \\
Respect for Rules and Officials & PES Teaching & 143 & 3.281 & .863 & & \\
& Coach Training & 210 & 3.300 & .912 & & \\
& Sports Management & 213 & 3.576 & .386 & 9.718 & .000 \\
& Total & 566 & 3.398 & .755 & & \\
Commitment to Responsibility in Sport & PES Teaching & 143 & 3.355 & .783 & & \\
& Coach Training & 210 & 3.284 & .787 & & \\
& Sports Management & 213 & 3.540 & .418 & 8.092 & .000 \\
& Total & 566 & 3.398 & .679 & & \\
Respect for Opponents & PES Teaching & 143 & 3.304 & .717 & & \\
& Coach Training & 210 & 3.364 & .782 & 6.751 & .001 \\
& Sports Management & 213 & 3.536 & .333 & & \\
& Total & 566 & 3.414 & .638 & & \\
\hline
\end{tabular}


Table 4. Analysis of Sportsmanship Orientation Scores according to "Grade" Variable

\begin{tabular}{lllllll}
\hline Scale/Sub Scale & Grade & $\mathbf{N}$ & $\mathbf{X}$ & St.d & $\mathbf{F}$ & $\mathbf{P}$ \\
\hline Sportsmanship Orientation Scale & First grade & 130 & 3.589 & .612 & & \\
& Second grade & 145 & 3.478 & .603 & & \\
& Third grade & 132 & 3.252 & .617 & 7.463 & .000 \\
& Fourth grade & 159 & 3.475 & .546 & & \\
& Total & 566 & 3.450 & .603 & & \\
Adherence to Social Conventions & First grade & 130 & 3.716 & .678 & & \\
& Second grade & 145 & 3.669 & .791 & & \\
& Third grade & 132 & 3.400 & .765 & 5.059 & .002 \\
& Fourth grade & 159 & 3.569 & .634 & & \\
Respect for Rules and Officials & Total & 566 & 3.589 & .725 & & \\
& First grade & 130 & 3.540 & .746 & & \\
& Second grade & 145 & 3.434 & .792 & & \\
& Third grade & 132 & 3.193 & .806 & 5.015 & .002 \\
& Fourth grade & 159 & 3.422 & .649 & & \\
& Total & 566 & 3.399 & .755 & & \\
Commitment to Responsibility in Sport & First grade & 130 & 3.532 & .733 & & \\
& Second grade & 145 & 3.393 & .667 & & \\
& Third grade & 132 & 3.207 & .665 & 5.640 & .001 \\
& Fourth grade & 159 & 3.454 & .626 & & \\
& Total & 566 & 3.398 & .679 & & \\
& First grade & 130 & 3.567 & .613 & & \\
& Second grade & 145 & 3.416 & .619 & & \\
& Third grade & 132 & 3.209 & .696 & 7.539 & .000 \\
& Fourth grade & 159 & 3.456 & .584 & & \\
& Total & 566 & 3.414 & .638 & & \\
\hline
\end{tabular}

Table 5. Analysis of Sportsmanship Orientation Scores according to "Type of Sport Played" Variable

\begin{tabular}{llllll}
\hline Scale/Sub Scale & Variable & Mean & St.d & t & p \\
\hline Sportsmanship Orientation Scale & Individual sports (187) & 3.390 & .689 & -1.659 & 0.09 \\
& Team Sports (379) & 3.479 & .554 & & \\
Adherence to Social Conventions & Individual sports (187) & 3.544 & .840 & 1.036 & 0.30 \\
& Team Sports (379) & 3.611 & .662 & & \\
Respect for Rules and Officials & Individual sports (187) & 3.321 & .845 & 1.715 & 0.08 \\
& Team Sports (379) & 3.437 & .705 & & \\
Commitment to Responsibility in Sport & Individual sports (187) & 3.377 & .787 & 0.526 & 0.59 \\
& Team Sports (379) & 3.409 & .621 & & \\
\multirow{2}{*}{ Respect for Opponents } & Individual sports (187) & 3.318 & .707 & 2.510 & 0.01 \\
& Team Sports (379) & 3.461 & .596 & & \\
\hline
\end{tabular}

According to the independent samples t-test performed to determine whether there were any significant differences between sportsmanship orientation levels of the participants of the study according to the type of sport they played, no significant difference was observed for the scale as a whole.

When the subdimensions of the scale were evaluated, however, a significant difference was observed in the "Respect for Opponents" subdimension in favour of those who engaged in team sports.

\section{Discussion and Conclusions}

The concept of sportsmanship expresses the fact that behaviours within sporting activity must conform to socio-ethical norms, that is, to the true spirit of sport (Yllmaz, Esentürk \& İlhan, 2017). Displaying this type of behaviour becomes difficult particularly among those who perform this activity as professionals, when expectations are based on winning.

Athletes who have the desire to win conceal the unethical behaviours that they carry out for this purpose and exhibit behaviour aiming to deceive everyone, especially referees. Following such behaviour, they may even 
resort to telling lies if this means not being caught. Such unethical behaviour is quite common among athletes whose sole aim is to win (Lumpkin, Stoll \& Beller, 2003).

People's behaviour is shaped according to the models that they observe around them, especially in their families. The role models for athletes raised in a sports environment are older athletes and the athletes' own trainers. Within this lies the necessity for lesson content in school curricula in which sport ethics and morality are taught. However, it is seen that in schools, lessons of this type, in which sports trainers are raised who can teach these values, are not adequately included in teaching programmes (Güven, 2009). It is considered that as a result of this, the number of sports trainers who give importance to a score culture, rather than to a sporting culture, will increase.

In this study, which was carried out with the aim of determining the sportsmanship orientations of students receiving education in the field of sport, the existing states of the participants with regard to their gender, the departments they attended, their class levels and the types of sport they engaged in were determined and the differences between the groups were evaluated.

The research findings revealed that the mean sportsmanship orientation levels $(X=3.45 \pm 0.603)$ of the university students educated in the field of sports sciences who took part in the study were at medium level.

Another finding obtained in the study was that the sportsmanship orientation scores of the sports education students differed according to gender. Accordingly, the gender variable was found to be a variable that affected the sportsmanship orientations of the students of physical education and sport. Female students had higher levels of sportsmanship orientations than male students.

Various studies on this subject can be found in the literature. In the study made by Mikail et al. (2017), Çalayır et al., (2017), Koç and Güllü, (2017), Şenel and Yıldız, (2016), Gürpınar and Kurşun (2013), in parallel with the findings of the present study, it was found that females had higher levels of sportsmanship orientations than males. Examining the related literature, it is seen that similar studies were made in different countries and with different variables. In some of these studies, different results were obtained with regard to the gender variable. In the studies carried out by Güllü and Şahin (2018) on national wrestlers, Miller, Roberts and Ommundsen (2004) on footballers, and Karanfil et al. (2017) on middle school students, it was determined that male athletes and students had higher levels of sportsmanship orientations. It can be said that the different findings obtained in these studies may be due to various factors, such as the different educational levels and curricula of the sample groups and the fact that the study areas were different.

In the current study, the analysis findings for the variable of the department attended by the PE and sports students revealed that the department they studied in had an effect on their sportsmanship orientations. It was observed that students studying in the sport management department had higher levels of sportsmanship orientations than students in the physical education teaching department and the coach training department. Since the syllabuses and the students' past sporting experiences were different, the finding of different sportsmanship orientations is to be expected, even though the participants of this study were studying at the same education institution.

In the examination of another variable of the study, that of class level, it was seen that for the scale as a whole, students in first grade had the highest levels of sportsmanship orientations. It is considered that together with the responsibility and excitement that accompany their recent arrival at university, the fact that first-year students are also more dependent on their trainers and instructors may have led to this result. The different results regarding class level may be due to the fact that as class level increases, more individual decisions are made. These findings also correspond to the literature (Güllü, 2018). Stating that unsportsmanlike behaviours increase as class level increases, Kaye and Ward (2010) reported that the rate of displaying such behaviours was higher in second grade. Similar findings were obtained in the studies made by Esentürk at al. (2010) and Koç, (2015).

Together with the increasing interest in sport nowadays, a number of activities are being organised related to the teaching of sport morality and ethical values. The most important of these are without doubt the activities of the Turkish Olympic Committee's Fair Play Commission. Moreover, a number of researchers have conducted various studies related to this concept. Some of these examine trainer-athlete relationships (Isoard-Gautheur, Trouilloud, Gustafsson \& Guillet-Descas, 2016; Vella, Oades \& Crowe, 2013; Choi, Cho \& Huh, 2013; Lafrenière, Jowett, Vallerand \& Carbonneau, 2011; Nazarudin, Fauzee, Jamalis, Geok \& Din, 2009) while others deal with subjects like sportsmanship orientations and fair play in relation to the type of sport played (Güllü, Keskin, Şahin \& Hanbay, 2018; Sezen-Balçikanli, 2014; Tsai \& Fung, 2005; Stornes, 2001).

In the current study, when the sportsmanship orientations of the PE and sports students were examined according 
to the type of sport they played, it was seen that there was no significant difference between the groups playing team and individual sports for the scale as a whole. However, when the scale subdimensions were examined, a significant difference in favour of team sport players was determined in the "respect for opponents" subdimension. It is believed that this situation may be due to the fact that team sport players engage in social relationships more than those who play individual sports.

In conclusion, the aim of this study was to examine the sportsmanship orientations of students in physical education and sports school with regard to certain variables.

In the tests to determine whether there were differences between the students participating in the study according to their personal information and the scores they obtained from the scale, statistically significant differences were found in the "gender", "department", "class" and "sport type" variables. It can be said that these findings reveal that in a general sense, the sportsmanship orientations of the participants were at a medium level.

The sportsmanship orientation levels of young people who will be future sports instructors in the country should be determined by conducting this research at other universities. According to the data obtained, rearrangements should be made in the sports policies and educational curricula that are to be created in line with the needs. Furthermore, with regard to gathering the required data for potential projects to be carried out, it is considered that importance should be given to the variety of studies of this type.

\section{References}

Balçıkanlı, G. (2010). Çok boyutlu sportmenlik yönelimi ölçeği'nin türkçe uyarlaması: geçerlik ve güvenirlik çalışması. Gazi beden eğitimi ve spor bilimleri dergisi, 15(1), 1-10.

Choi, H., Cho, S., \& Huh, J. (2013). The association between the perceived coach-athlete relationship and athletes' basic psychological needs. Social Behavior and Personality: an international journal, 41(9), https://doi.org/10.2224/sbp.2013.41.9.1547

Cremades, J. G. (2014). Becoming a sport, exercise, and performance psychology professional: A global perspective. Psychology Press. https://doi.org/10.4324/9780203093184

Cronbach, L. J. (1990). Essentials of Psychological Testing. New York, Happer and Row publishers.

Çalayır, Ö., Yıldız, N., Yaldız, Ö., \& ve Çoknaz, H. (2017). Hokey müsabakalarına katılan sporcuların beden eğitimi dersi sportmenlik davranışlarının incelenmesi. $\ddot{I} U$ Spor Bilimleri Dergisi., 7(2), 1303-1414. Retrieved from http://dergipark.org.tr/iuspor/issue/32815/346966

Esentürk, O. K., İlhan, E. L., \& Çelik, O. B. (2015). Examination of high school students' sportsmanlike conducts in physical education lessons according to some variability. Science, Movement and Health, 15(2), 627-634.

Ford, D. W., Jubenville, C. B., \& Phillips, M. B. (2012). The effect of the STAR Sportsmanship education module on parents' self-perceived sportsmanship behaviors in youth sport. Journal of Sport Administration \& Supervision, 4(1), 114-126.

Güllü, S. (2018). Sporcuların antrenör-sporcu ilişkisi ile sportmenlik yönelimleri üzerine bir araştırma. SPORMETRE, 16(4), 190-204. Retrieved from http://dergipark.org.tr/spormetre/issue/40788/482295

Güllü, S. ve Şahin, S. (2018). Milli güreşçilerin sportmenlik yönelim düzeyleri üzerine bir araştırma. Turkish Studies, 13(18), 705-718. http://dx.doi.org/10.7827/TurkishStudies.14152

Güllü, S., Keskin, B., Şahin, O., \& ve Hanbay, E. (2018). Examining the effect of coach-athlete relationship on sports passion in individual sports. Oral Presentation. 16th International Sport Sciences Congress. Antalya.

Gürpınar, G., \& Kurşun, S. (2013). Basketbolcuların ve Futbolcuların Sportmenlik Yönelimleri. Mediterranean Journal of Humanities, III(1), 171-176. https://doi.org/10.13114/MJH/20131660

Güven Ö. (2009). Milli beden eğitimi spor politikası ve altıncı spor şurası. Türk Yurdu; Nisan, 29, 60-65.

Hacıcaferoğlu, S., Selçuk, M. H., Hacıcaferoğlu, B., \& Karataş, Ö. (2015). Ortaokullarda işlenen beden eğitimi ve spor derslerinin, sportmenlik davranışlarına katkısının bazı değişkenler açısından incelenmesi. International Journal of Science Culture and Sport (IntJSCS), 3(4), 557-566.

Isoard-Gautheur, S., Trouilloud, D., Gustafsson, H., \& Guillet-Descas, E. (2016). Associations between the perceived quality of the coach-athlete relationship and athlete burnout: An examination of the mediating role of achievement goals. Psychology of Sport and Exercise, 22, 210-217.

https://doi.org/10.1016/j.psychsport.2015.08.003 
Karafil, A., Y., Atay, E., Ulaş, M., \& ve Melek, C. (2017). Spora katılımın beden eğitimi dersi sportmenlik davranışları üzerine etkisinin araştırılması. CBÜ Beden Eğitimi ve Spor Bilimleri Dergisi, 12(2), 1-11.

Kaye, M. P., \& Ward, K. P. (2010). Participant-related differences in high school athletes' moral behavior. Athletic Insight: The Online Journal of Sport Psychology, 12(1), 1-17.

Koç, Y., \& Güllü, M. (2017). Lise öğrencilerinin beden eğitimi dersi sportmenlik davranışlarının bazı değişkenlere göre incelenmesi. Spormetre, 15(1), 19-30. https://doi.org/10.1501/Sporm_0000000304

Koç, Y. (2013). Beden eğitimi dersi sportmenlik davranışı ölçeği (BEDSDÖ): Geçerlik ve güvenirlik çalışması. Erzincan Üniversitesi Ë̆itim Fakültesi Dergisi, 15(1), 96-114.

Lafrenière, M. A. K., Jowett, S., Vallerand, R. J., \& Carbonneau, N. (2011). Passion for coaching and the quality of the coach-athlete relationship: The mediating role of coaching behaviors. Psychology of Sport and Exercise, 12(2), 144-152. https://doi.org/10.1016/j.psychsport.2010.08.002

Lumpkin, A., Stoll, K. S., \& Beller, M. J. (2003). Sport ethics: application for fair play (3rd ed.). USA: McGrawHill.

Mikail, T. E. L., Yaman, Ç., \& Altun. M. Spor bilimleri fakültesi öğrencilerinin sportmenlik davranışları hakkındaki görüşleri. Uluslararası Kültürel ve Sosyal Araştırmalar Dergisi (UKSAD), 3(Special Issue 2), 16-26.

Miller, W. B., Roberts, C., \& Ommundsen, Y. (2004). Effect of motivational climate on sportspersonship among competitive youth male and female football players. Scandinavian Journal of Medicine \& Science in Sports, 14(3), 193-202.https://doi.org/10.1111/j.1600-0838.2003.00320.x

Nazarudin, M. N. B., Fauzee, O. S. M., Jamalis, M., Geok, K. S., \& Din, A. (2009). Coaching leadership styles and athlete satisfaction among Malaysian University Basketball team. Research Journal of International Studies, 9(1), 4-11.

Öztürk, Ö. T., \& Soytürk, M. (2015). Beden Eğitimi, Müzik ve Resim/Görsel Sanatlar Öğretmenlerinin İletişim Becerilerinin İncelenmesi. Ahi Evran Üniversitesi Kırşsehir Eğitim Fakültesi Dergisi, 16(3), 39-50.

Pehlivan, Z. (2004). Fair-Play Kavramının Geliştirilmesinde Okul Sporunun Yeri ve Önemi. Spormetre Beden Eğitimi ve Spor Bilimleri Dergisi, II(2), 49-53. https://doi.org/10.1501/Sporm_0000000028

Şenel, E., \& Yıldız, M. (2016). Beden eğitimi ve spor yüksekokulunda öğrenim gören öğrencilerin bedensel/kinestetik zeka ve sportmenlik eğilimleri arasındaki ilişkinin incelenmesi. Uluslararası Hakemli Akademik Spor Sağllk ve Tip Bilimleri Dergisi, 19, 54-61.

Sezen-Balçikanli, G. (2014). Fair play in professional sports: Sportspersonship orientations of futsal players. FairPlay, Revista de Filosofia, Ética y Derecho Del Deporte, 2(1), 33-49.

Siedentop, D., Hastie, P. A., \& Mars van der H. (2004). Complete Guide to Sport Education. (pp. 1-11). Champaign, IL: Human Kinetics.

Stewart, C. C. (2014). Sportsmanship, Gamesmanship, and the implications for coach education. Strategies, 27(3), 3-7. https://doi.org/10.1080/08924562.2014.938878

Stornes, T. (2001). Sportspersonship in elite sports: On the effects of personal and environmental factors on the display of sportspersonship among elite male handball players. European Physical Education Review, 7(3), 283-304. https://doi.org/10.1177/1356336X010073004

Stornes, T., \& Bru, E. (2002). Sportspersonship and Perceptions of Leadership: An Investigation of Adolescent Handball Players'Perception of sportspersonship and Associations with Perceived Leadership. European Journal of Sport Science, 2(6), 1-15. https://doi.org/10.1080/17461391.2002.10142577

Tanrıverdi, H. (2012). Spor ahlak1 ve şiddet. The Journal of Academic Social Science Studies, 5(8), 1071-1093. http://dx.doi.org/10.9761/JASSS_361

Tel, M. (2014). Türk toplum yaşantısında Fair Play. International Journal of Science Culture and Sport, 1, 694-704. https://doi.org/10.14486/IJSCS139

Toohey, K., \& Veal, A. J. (2000). The Olympic Games: A Social Science Perspective. UK: Cabi Puplishing. Library of Congress Cataloging.

Tsai, E., \& Fung, L. (2005). Sportspersonship in youth basketball and volleyball players. Athletic Insight, 7(2), $37-46$. 
Vallerand, R. J., \& Losier, G. F. (1994). Self-Determined Motivation and Sportsmanship Orientations: An Assessment of their Temporal Relationship. Journal of Sport and Exercise Psychology, 16, $229-245$. https://doi.org/10.1123/jsep.16.3.229

Vella, S. A., Oades, L. G., \& Crowe, T. P. (2013). The relationship between coach leadership, the coach-athlete relationship, team success, and the positive developmental experiences of adolescent soccer players. Physical education and sport pedagogy, 18(5), 549-561. https://doi.org/10.1080/17408989.2012.726976

Veronica, P., \& Masari, G. A. (2011). Comparative analysis of athletes' fair play attitude according to spesific variables conditioned by sport trainig and competition. Social and Behavioral Science, 12, $24-29$. https://doi.org/10.1016/j.sbspro.2011.02.006

Weiss, O. (2001). Identity reinforcement in sport. International Review for the Sociology of Sport, 36(4), 393-4058. https://doi.org/10.1177/101269001036004002

Yılmaz, A., Esentürk, O. K., \& İlhan, E. L. (2017). Ortaokul öğrencilerinin ahlaki gelişimleri açısından sportmenlik yönelimleri. Journal of Human Sciences, 14(4), 4969-4988.

https://doi.org/10.14687/jhs.v14i4.4869

\section{Copyrights}

Copyright for this article is retained by the author(s), with first publication rights granted to the journal.

This is an open-access article distributed under the terms and conditions of the Creative Commons Attribution license (http://creativecommons.org/licenses/by/4.0/). 